\title{
OPTIMALISASI DANA DESA MELALUI ANALISIS PEMBELANJAAN DI DESA PABELAN KABUPATEN SEMARANG
}

\section{VILLAGE FUNDS OPTIMIZATION THROUGH SHOPPING ANALYSIS IN PABELAN VILLAGE OF SEMARANG DISTRICT}

\author{
Lutfi Ade Yulianti, Anita Wahyu Alviani, Muhammad Muchlisun, Ahmad Ulil Albab Al Umar, Saiful \\ Anwar
}

Prodi Akuntansi Syariah, Fakultas Ekonomi dan Bisnis Islam, IAIN Salatiga

Krajan RT 03/RW 01, Lemah Ireng, Bawen, Kabupaten Semarang

Alamat korespondensi : lutfiade07@gmail.com

(Tanggal Submission: 16 April 2020, Tanggal Accepted: 30 April 2020)

\begin{abstract}
ABSTRAK
Kegiatan Penelitian dan Pengabdian kepada masyarakat ini bertujuan untuk merumuskan gagasan dalam rangka optimalisasi penggunaan dana desa. Gagasan tersebut dihasilkan melalui pelaksanaan kajian ilmiah, yaitu studi kasus penggunaan dana di Desa Pabelan Kabupaten Semarang. Bentuk kegiatan ini adalah analisa pertanggungjawaban dana desa di Kabupaten Semarang, identifikasi masalah yang terjadi, dan mencari solusi untuk masalah tersebut. Kegiatan ini dilakukan dengan metode penelitian kualitatif deskriptif dengan pendekatan studi kasus. Pengumpulan data dilakukan melalui wawancara dan analisis dokumen. Penelitian dilakukan di sebuah desa di Kabupaten Semarang, yaitu di Desa Pabelan. Hasil penelitian menunjukkan bahwa akuntabilitas dana desa di Kabupaten Semarang belum berjalan dengan baik. Ada beberapa masalah dalam pertanggungjawaban dana desa di Kabupaten Semarang, termasuk laporan pertanggungjawaban yang disampaikan kepada Bupati tidak lengkap, laporan pertanggungjawaban tentang pelaksanaan APBD terlambat diinformasikan kepada publik dan ada informasi yang tidak sinkron dari informan yang diwawancarai. Berdasarkan hal tersebut, dihasilkan sebuah gagasan, yaitu diperlukan adanya pelatihan secara intensif agar kualitas perangkat desa menjadi lebih baik sehingga dapat menyusun laporan keuangan secara lengkap, perangkat desa perlu lebih berinisiatif serta tanggap dalam pelaksanaan pertanggungjawaban dana desa, perangkat desa diharapkan lebih terbuka sehingga tidak terjadi asimetric information.
\end{abstract}

Keywords : Pertanggungjawaban, Dana Desa, Kabupaten Semarang

\section{PENDAHULUAN}

UU No. 6 Tahun 2014 berisi tentang Desa mengamanatkan Pemerintah Pusat untuk mengalokasikan dana desa dalam Anggaran Pendapatan Belanja Negara (APBN). PP Nomor 8 Tahun 2016, pasal 1, angka 2 menjelaskan bahwa Dana desa yang berasal dari Anggaran Pendapatan Belanja Negara (APBN) yang diberikan pada desa dan ditransfer melalui Anggaran Pendapatan
Belanja Daerah (APBD) Kabupaten atau Kota yang digunakan untuk pembiayaan dalam hal kegiatan pemerintah, pelaksanaan pembangunan, pembinaan dan pemberdayaan masyarakat. Salah satu dampak yang ditimbulkan dengan adanya dana desa dapat dilihat dari berkembangnya otonomi daerah, seperti terjadinya perubahan sistem disuatu daerah yang dulunya memakai sistem sentralistik (segala sesuatu yang berkaitan dengan pemerintahan akan secara langsung diatur oleh pemerintah pusat) kemudian berubah 
menjadi sistem desentralistik (pemerintah pusat langsung memberikan wewenang kepada pemerintah daerah agar dapat mengatur daerahnya sendiri) . Desentralistik dalam otonomi daerah juga dapat diartikan adanya pelimpahan wewenang yang terjadi antara pemerintahan pusat ke pemerintahan daerah (Tikollah \& Ngampo, 2018). Pengukuran kinerja keuangan pemerintah daerah merupakan suatu cara untuk menginformasikan apakah pemerintah telah berhasil mengelola keuangan daerahnya. Selain itu pengukuran kinerja pemerintah daerah untuk memastikan fiscal yang ditransfer ke daearah apakah sudah berhasil atau gagal. (Zelmiyanti, 2016)

Pengalokasian dana desa dalam APBN merupakan bentuk pengakuan negara terhadap keberadaan desa (Direktur Pembiayaan dan Transfer Non Dana Perimbangan, 2017). Penyaluran dana desa memiliki tujuan untuk dapat meningkatkan kesejahteraan dalam masyarakat dan terdapat pemerataan pembangunan di desa dengan cara meningkatan pelayanan publik, mengembangkan tingkat perekonomian desa, mengatasi kesenjangan pembangunan antar desa, dan dapat menjadikan masyarakat di desa sebagai subjek dari pembangunan (Madjid, 2017). Hal ini sama dengan pendapat Nawacita yaitu membangun Indonesia mulai dari pinggiran dengan cara memperkuat daerah desa guna membentuk kerangka negara kesatuan.

Salah satu aspek yang sangat penting untuk diperhatikan dalam melaksanakan otonomi daerah dan sistem desentralisasi ialah pengelolaan keuangan daerah yang biasa dikenal dengan Anggaran Pendapatan Belanja Daerah (APBD), dimana pengelolaan ini harus dilakukan secara hati-hati dan berdasarkan peraturan yang sudah ditetapkan. Selain Aggaran Pendapatan Belanja Daerah (APBD) untuk melaksanakan otonomi daerah juga terdapat pengelolaan Anggaran Pendapatan Belanja Desa (APBDes) yang dikelola secara teliti berdasarkan peraturan yang ditetapkan. APBDes merupakan rancangan tahunan tentang keuangan pemerintahan desa yang didalamnya berisi konsep pemerintah desa untuk mencapai tujuan dalam membangun dan mengatur desanya (Utomo, Sudarmo, \& Suharto, 2018). Peran Akuntansi Pemerintahan merupakan hal yang sangat penting dalam mengelola keuangan publik agar terwujudnya tata laksana pemerintahan yang teratur, mulai dari tata laksana keuangan pusat, daerah, maupun desa. Desa merupakan unit organisasi pemerintah yang akan berdekatan langsung pada masyarakat dengan kondisi segala latar belakang kepentingan dan kebutuhannya mempunyai peranan yang sangat penting (Orangbio, Tinangon, \& Gerungai, 2017). Oleh karena itu, pemerintah mengeluarkan kebijakan mengenai Alokasi Dana Desa (ADD) yang salah satu tujuannya sebagai bentuk dari desentralisasi keuangan desa yang mandiri. Alokasi Dana Desa (ADD) merupakan dana yang diberikan oleh pemerintah Kabupaten atau Kota kepada desa, yang berasal dari sebagian dana perimbangan pada keuangan pusat dan daerah yang kemuadian diterima oleh Kabupaten atau Kota agar dapat memenuhi semua sektor di dalam masyarakat, juga berguna dalam memudahkan pemerintah untuk melaksanakan semua kegiatan pemerintahan, pembangunan dan pemberdayaan masyarakat desa, dan meningkatkan swadaya gotong royong masyarakat. (Siti Ainul Wida \& Taufik Kurrohman, 2017).

Pengelolaan keuangan di desa harus didasari dengan asas-asas yang akuntabel, partisipatif, transparan serta dilakukan secara tertib dan sesuai anggaran. Keuangan desa harus disiapkan informasi secara baik guna Meningkatkan akuntabilitas dan tranparansi serta menginformasikan kepada masyarakat melalui papan desa ataupun media yang lain. Akuntabilitas pemerintahan desa merupakan tolok ukur kemampuan pemerintah desa dalam melaksanakan tanggungjawabnya di dalam kegiatan pembangunan seperti masalah keuangan yang telah disusun dalam APPBDes dan Alokasi Dana Desa (ADD) merupakan salah satu komponen di dalamnya (Farida, Jati, \& Harventy, 2018). Dalam mengelola keuangan desa yang baik harus didasarkan dengan pedoman yang sudah diatur oleh pemerintah yakni terletak dalam Permendagri No. 113 Tahun 2014 yang berisi tentang pengelolaan keuangan desa itu mencakup 5 aspek penting yaitu perencanaan, pelaksanaan, penatausahaan, pelaporan dan pertanggungjawaban. Dibalik besarnya dana yang dikelola oleh desa dan harapan untuk terwujudnya pemerataan pembangunan desa, juga terdapat kekhawatiran dimana ketidaksiapan Sumber Daya 
Manusia (SDM) akan mengakibatkan pengelolaan dana desa menjadi tidak transparan. Minimnya pendapatan yang diperoleh desa menjadi salah satu kendala Pemerintahan Desa untuk menjadikan pemerintahan desa menjadi pemerintahan yang baik. Meskipun Dana yang diporeleh Desa adalah dana perimbangan yang diterima oleh Kabupaten atau Kota, namun dana tersebut sangat dinantikan oleh Pemerintah Desa, karena itu Dana Desa sangat membantu keuangan desa (Winari, 2018). Adapun teori yang digunakan pada penelitian ini yaitu Teori Keagenan (Agency Theory) yang menjelaskan hubungan keagenan yang terjadi antara satu atau lebih orang (principal) dengan orang lain (agent) dalam sebuah kontrak, dimana agent diminta untuk mewakili principal dalam membuat keputusan (Jensen \& Meckling, 1976)

Berdasarkan pemaparan latar belakang diatas, penulis menjadi tertarik untuk meneliti tentang pertanggungjawaban dana desa di Desa Pabelan Kabupaten Semarang karena terindikasi belum sesuai dengan Permendagri No. 113 Tahun 2014 yaitu laporan pertanggungjawaban yang disampaikan kepada Bupati belum lengkap, laporan pertanggungjawaban realisasi pelaksanaan APBDes terlambat diinformasikan kepada masyarakat dan adanya ketidaksinkronan informasi dari para informan yang diwawancarai. Sehingga dapat dirumuskan bahwa penelitian ini bertujuan untuk menganalisis pelaksanaan pertanggungjawaban dana desa di Kabupaten Semarang serta untuk mengidentifikasi permasalahan dalam pertanggungjawaban dana desa di Kabupaten Semarang dan mencari solusi atas permasalahan tersebut.

\section{METODE KEGIATAN}

\section{Lokasi Kegiatan}

Kegiatan ini dilaksanakan di Kantor Desa Pabelan, Kecamatan Pabelan, Kabupaten Semarang.

\section{Sumber Data Penelitian}

Data-data yang akan digunakan dalam penelitian ini terdiri dari data primer dan data sekunder. Data primer merupakan data yang didapatkan sendiri oleh peneliti, dalam penelitian ini data primer yang dimaksud adalah data yang diperoleh berdasarkan hasil wawancara dengan Kepala Desa, Sekertaris Desa, dan Bendahara Desa yang berada di Desa Pabelan. Sedangkan data sekunder adalah data yang diperoleh peneliti dari sumber yang sudah ada. Dalam penelitian ini data sekunder yang digunakan yaitu laporan keuangan desa.

\section{Teknik Pengumpulan Data}

Dalam kegiatan ini, teknik pengumpulan data adalah sebagai berikut :

1. Observasi dan Wawancara

Observasi ialah proses-proses pengamatan dan ingatan. Inti dari observasi adalah adanya perilaku yang tampak dan tujuan yang ingin dicapai wawancara adalah sebuah proses interaksi komunikasi yang dilakukan oleh setidaknya dua orang, atas dasar ketersediaan dan dalam setting alamiah, dimana arah pembicaraan mengacu kepada tujuan yang telah ditetapkan dengan mengedepankan trust dalam landasan utama dalam proses memahami. (Herdiansyah, 2013).

2. Dokumentasi

Dokumen merupakan catatan peristiwa yang sudah berlalu yang bisa berbentuk tulisan, gambar, atau karya-karya monumental dari seseorang. Teknik dokumentasi merupakan alat pelengkap dari penggunaan teknik observasi dan wawancara dalam penelitian kualitatif. (Sugiyono, 2007)

\section{Instrumen penelitian}

Instrumen penelitian merupakan suatu alat yang digunakan untuk memepermudah metode yang akan dipakai dalam melakukan penelitian. Penelitian ini menggunakan 2 alat bantu, yakni :

1. Pedoman wawancara

Pedoman wawancara digunakan agar wawancara yang dilakukan tidak menyimpang dari tujuan peneliti. Pedoman ini disusun tidak hanya berdasarkan tujuan penelitian, tetapi juga berdasarkan peraturan pemerintah dalam negeri yang berkaitan dengan masalah yang diteliti.

2. Alat perekam

Alat perekam berguna sebagai alat bantu pada saat wawancara, agar peneliti dapat berkonsentrasi pada proses pengambilan data 
tanpa harus berhenti untuk mencatat jawaban-jawaban dari subjek.

\section{HASIL DAN PEMBAHASAN}

\section{Pertanggungjawaban dana desa di Desa Pabelan Kabupaten Semarang}

Permendagri No 113 Tahun 2014 merupakan acuan yang digunakan dalam pelaksanaan pertanggungjawaban dana desa. Di dalamnya mencakup hal-hal yang harus dilakukan oleh desa sebagai wujud pertanggungjawaban atas dana desa yang diterima. Berdasarkan wawancara yang telah dilakukan di Desa Pabelan, diketahui bahwa pertanggungjawaban dana desa di Kabupaten Semarang belum berjalan dengan baik. Hal ini dapat dilihat di tabel perbandingan berikut :

Tabel 1. Kesesuaian Pelaksanaan Pertanggungjawaban Dana Desa di Kabupaten Semarang dengan Permendagri No 113 Tahun 2014

\begin{tabular}{|c|c|c|c|c|}
\hline \multirow[t]{2}{*}{ No } & \multirow{2}{*}{$\begin{array}{l}\text { Tahap pertanggungjawaban } \\
\text { berdasarkan Permendagri No } 113 \\
\text { Tahun } 2014\end{array}$} & \multicolumn{2}{|c|}{$\begin{array}{l}\text { Hasil penelitian di } \\
\text { Desa Pabelan } \\
\text { tahun } 2019 \\
\end{array}$} & \multirow[t]{2}{*}{ Bukti } \\
\hline & & Sudah & Belum & \\
\hline 1 & $\begin{array}{l}\text { Kepala Desa menyampaikan laporan } \\
\text { pertanggungjawaban realisasi } \\
\text { pelaksanaan APBDesa kepada } \\
\text { Bupati/Walikota setiap akhir tahun } \\
\text { anggaran }\end{array}$ & $\mathbf{v}$ & & $\begin{array}{l}\text { Kepala Desa Pabelan telah melaporkan } \\
\text { realisasi dana desa kepada Bupati melalui } \\
\text { Camat satiap tahap pencairan dana lalu } \\
\text { melaporkan laporan secara global setiap } \\
\text { akhir tahun }\end{array}$ \\
\hline \multirow[t]{4}{*}{2} & $\begin{array}{lr}\text { Laporan } & \text { pertanggungjawaban } \\
\text { realisasi } & \text { pelaksanaan APBDesa } \\
\text { kepada Bupati/Walikota terdiri dari : }\end{array}$ & & & \\
\hline & $\begin{array}{l}\text { Laporan } \quad \text { Pertanggungjawaban } \\
\text { Realisasi Pelaksanaan APBDesa }\end{array}$ & $\mathbf{v}$ & & $\begin{array}{l}\text { Desa Pabelan sudah melaporkan Laporan } \\
\text { Pertanggungjawaban Realisasi Pelaksanaan } \\
\text { APBDesa (terlampir) }\end{array}$ \\
\hline & Laporan Kekayaan Milik Desa & & $\mathbf{v}$ & $\begin{array}{l}\text { Desa Pabelan sudah membuat Laporan } \\
\text { Kekayaan Milik Desa namun tidak ikut } \\
\text { dilaporkan kepada Bupati pada akhir tahun }\end{array}$ \\
\hline & $\begin{array}{l}\text { Laporan Program Pemerintah dan } \\
\text { Pemerintah Daerah yang Masuk ke } \\
\text { Desa }\end{array}$ & & $\mathbf{v}$ & $\begin{array}{l}\text { Desa Pabelan tidak melaporkan Laporan } \\
\text { Program Pemerintah dan Pemerintah } \\
\text { Daerah yang Masuk ke Desa kepada Bupati }\end{array}$ \\
\hline 3 & $\begin{array}{l}\text { Laporan realisasi } \quad \text { dan } \\
\text { pertanggungjawaban realisasi } \\
\text { pelaksanaan APBDesa disampaikan } \\
\text { kepada masyarakat secara tertulis } \\
\text { dan dengan media informasi yang } \\
\text { mudah diakses oleh masyarakat }\end{array}$ & & $\mathbf{v}$ & $\begin{array}{l}\text { Hingga bulan Mei } 2019 \text { Desa Pabelan belum } \\
\text { menyampaikan Laporan realisasi dan } \\
\text { pertanggungjawaban realisasi pelaksanaan } \\
\text { APBDesa kepada masyarakat sebagai bentuk } \\
\text { transparansi }\end{array}$ \\
\hline
\end{tabular}

Permendagri No 113 tahun 2014 merupakan peraturan yang dikeluarkan sebagai acuan dalam kegiatan perencanaan, pelaksanaan, penatausahaan, pelaporan, serta pertanggungjawaban dana desa. Mengenai pertanggunggjawaban dana desa, dalam Permendagri No 113 Tahun 2014 diuraikan berbagai hal yang harus dilakukan oleh desa penerima dana desa dalam mewujudkan pertanggungjawaban yang baik. Diantaranya ialah :

- Kepala Desa melaporkan laporan pertanggungjawaban realisasi pelaksanaan
APBDesa kepada Bupati/Walikota setiap akhir tahun anggaran.

- Laporan pertanggungjawaban realisasi APBDesa kepada Bupati/Walikota terdiri dari Laporan Pertanggungjawaban Realisasi Pelaksanaan APBDes, Laporan Kekayaan Milik Desa, dan Laporan Program Pemerintah dan Pemerintah Daerah yang Masuk ke Desa.

- Laporan realisasi dan pertanggungjawaban realisasi pelaksanaan APBDesa disampaikan kepada masyarakat secara tertulis dan dengan media informasi yang mudah diakses oleh 
masyarakat. Namun, pada kenyataannya halhal tersebut belum seluruhnya terlaksana di Desa Pabelan Kabupaten Semarang. Disana masih terdapat beberapa hal yang belum terlaksana, sehingga menjadikan pelaksaan pertanggungjawaban dana desa di Desa Pabelan Kabupaten Semarang belum terlaksana dengan baik.

\section{Pelaksanaan pertanggungjawaban dana desa di Desa Pabelan Kabupaten Semarang}

Pelaksanaan pertanggungjawaban dana desa di Desa Pabelan Kabupaten Semarang belum berjalan dengan baik karena belum melaksanakan beberapa hal yang diatur dalam Permendagri No 113 Tahun 2014. Hal ini menyebabkan munculnya berbagai permasalahan dalam pelaksanaan pertanggungjawaban dana desa di Kabupaten Semarang. Permasalahan tersebut meliputi laporan yang disampaikan kepada Bupati belum lengkap yaitu belum mencakup Laporan Kekayaan Milik Desa dan Laporan Program Pemerintah dan Pemerintah Daerah yang Masuk ke Desa, laporan pertanggungjawaban realisasi pelaksanaan APBDes terlambat diinformasikan kepada masyarakat yang terjadi pada awal penerimaan dana desa serta pada tahun 2019, dan adanya ketidaksinkronan informasi dari para narasumber yang diwawancarai dimana kedua narasumber menyampaikan informasi yang berbeda atas pertanyaan yang sama.

Pertanggungjwaban dana desa di Desa Pabelan Kabupaten Semarang belum berjalan dengan baik karena ada beberapa permasalahan dalam pelaksanaannya, yaitu :

1) Laporan yang disampaikan kepada Bupati belum lengkap

Permendagri Nomor 113 tahun 2014 menyatakan bahwa kepala desa harus melaporkan laporan pertanggungjawaban kepada Bupati setiap akhir periode. Laporan pertanggungjawaban tersebut terdiri dari Laporan Pertanggungjawaban Realisasi Pelaksanaan, Laporan Kekayaan Milik Desa dan Laporan Program Pemerintah yang Masuk ke Desa. Sedangkan pada tahun 2018 kepala desa Pabelan hanya menyampaikan Laporan Pertanggungjawaban Realisasi Pelaksanaan dan tidak melaporkan Laporan Kekayaan Milik Desa. $\mathrm{Hal}$ ini terjadi karena adanya keterbatasan pemahaman perangkat desa dalam membuat laporan tersebut. Selain itu Laporan Program Pemerintah yang Masuk ke Desa tidak dilaporkan karena pada tahun 2018 tidak ada progam pemerintah yang masuk ke Desa Pabelan. Untuk itu diperlukan adanya pelatihan untuk meningkatkan kualitas sumber daya perangkat desa.

Hasil dari penelitian (Utomo et al., 2018) menunjukkan bahwa pertanggungjawaban keuangan Desa Campurasri kepada publik telah dilakukan sesuai prinsip akuntabilitas dalam pengelolaan keuangan desa baik secara vertical (Kepada Bupati) maupun horizontal (Kepada Masyarakat). Selain itu penelitian tersebut juga menjelaskan bahwa pemerintah desa harus bisa menyelenggarakan pencatatan atau minimal melakukan pembukuan atas transaksi keuangannya sebagai wujud pertanggungjawaban keuangan yang dilakukannya.Sedangkan pada temuan pada penelitian kami menunjukkan bahwa pelaporan pertanggungjawaban dana desa di Desa Pabelan belum lengkap.

Hasil dari peneltian (Kurnia, Sebrina, \& Halmawati, 2019) menjelasakan Permendagri No. 113 Tahun 2014 pasal 41 Laporan Pertanggungjawaban Realisasi Pelaksanaan APBDesa disampaikan paling lambat satu bulan setelah tahun anggaran. Di Desa-Desa yang ada pada kecamatan Luhak Nan Duo dalam menyampaikan Laporan Pertanggungjawaban Realisasi Pelaksanaan APBDesa mengalami keterlambatan, hal ini disebabkan karena Karena adanya perbedaaan pendapat antara Wali Nagari dan Bamus sewaktu pengesahan APB perubahan, serta adanya kendala lainnya. Sedangkan hasil dari penelitian kami sama-sama mengalami keterlambatan, tetapi faktor yang menjadi penyebab keterlambatan penyampaian laporan pertanggungjawaban dana desa tersebut ialah Sumber Daya Manusia (SDM) yang kurang mumpuni, sehingga dibutuhkan pelatihan untuk meningkatkan kualitas Sumber daya manusianya.

Pelatihan tersebut sebenarnya sudah ada di Desa Pabelan contohnya berupa Bimtek. Namun dalam pelaksanaanya belum berjalan dengan efektif dikarenakan hanya ada beberapa perangkat desa yang mengikuti pelatihan tersebut. Selain itu juga dikarenakan peserta dalam pelatihan tersebut terlalu banyak sehingga tidak bisa terfokus. Jadi kedepannya diharapkan pelatihan yang ada bersifat menyeluruh dan terfokus. Sehingga dapat 
meningkatkan kualitas perangkat desa dalam pelaksanaan pertanggungjawaban dana desa.

2) Keterlambatan publikasi APBDes kepada masyarakat

Permasalahan berikutnya yang terdapat dalam pelaksanaan pertanggungjawaban dana desa di Desa Pabelan adalah terlambatnya pencetakan MMT APBDes sebagai bentuk publikasi ke masyarakat pada awal penerimaan dana desa dan pada tahun 2019. Seperti yang kita ketahui bahwa berdasarkan Permendagri Nomor 113 Tahun 2014, bentuk publikasi tersebut biasanya berupa MMT yang dipasang di setiap dusun setiap awal tahun. Desa Pabelan menerima dana Desa pertama kali pada tahun 2015 akan tetapi hingga tahun 2016 desa Pabelan belum melakukan langkah publikasi kepada masyarakat. Hal ini dikarenakan perangkat desa belum memahami peraturan mengenai dana desa sehingga pelaksanaanya pun terhambat. Selain itu, dikarenakan pemahaman yang masih kurang tersebut, perangkat desa mengharapkan adanya instruksi atas tiap langkah yang harus dilakukan dalam pelaksanaan pertanggungjawaban dana desa dari pihak atasan. Namun pada tahun 2015 dan 2016 tidak ada intruksi dari atasan sehingga tidak ada perwujudan publikasi ke masyarakat.

Hasil dari penelitian (Orangbio et al., 2017) diperoleh bahwa pertanggungjawaban keuangan Desa Inobonto II, dimana dalam hal ini terjadi ketidaaksesuaian yaitu pertanggungjawaban belum diinformasikan kepada seluruh masyarakat Desa Inbonto II, sedangkan hasil penelitian kami menunjukkan bahwa pertanggungjawaban dana desa di Desa Pabelan telah sesuai dengan permendagri no 113 tahun 2014. Pertanggungjawaban dana Desa di Desa Pabelan sudah diinformasikan kepada seluruh masyarakat akan tetapi dalam penyampainnya tidak sesuai waktu yang telah ditetapkan.

Hasil dari penelitian (Sulumin, 2015) menunjukkan bahwa pertanggungjawaban secara langsung kepada masyarakat. Hal tersebut terjadi karena ada transparansi atau keterbukaan oleh pemerintah desa sebagai pengelola Alokasi Dana Desa kepada masyarakat dalam bentuk informasi penggunaan dana Alokasi Dana Desa. Sedangkan pada penelitian kami ditemukan hasil bahwa Desa Pabelan telah melakukan transparansi kepada masyarakat akan tetapi penyampaiannya mengalami keterlambatan.

Selain keterlambatan publikasi pada awal penerimaan dana desa, pada tahun 2019 juga terjadi keterlambatan publikasi ke masyarakat dimana hingga bulan Mei 2019 di Desa Pabelan belum terdapat media publikasi tersebut. Hal ini dikarenakan perangkat desa yang tidak bergegas menyusun APBDes tahun 2019. Akan tetapi dibalik alasan tersebut, ternyata terdapat alasan lain yaitu dikarenakan Perbup (Peraturan Bupati) yang digunakan sebagai dasar hukum penyusunan APBDes belum disusun, sehingga perangkat desa di Desa Pabelan belum menyusun APBDes hingga dikeluarkannya Perbup tersebut. Hal ini dikarenakan dalam pemerintahan daerah terjalin teori keagenan (Agency Theory).

Pada sektor publik hubungan keagenan tersebut juga dapat dilihat dalam penyusunan anggaran. Pemerintah daerah yang dimaksud disini yakni, provinsi menyusun anggaran kemudian anggaran tersebut diserahkan ke pusat setelah adanya pengesahan dari pusat pemerintah daerah menjalankan kegiatan berdasarkan anggaran tadi. Akhirnya pemerintah daerah harus mempertanggung jawabkan realisasi anggaran terhadap pemerintah pusat.

Pada pemerintahan, peraturan perundangundangan secara implisit merupakan bentuk kontrak antara eksekutif, legislatif, dan publik. Dalam peraturan tersebut dinyatakan semua kewajiban dan hak pihak-pihak yang terlibat dalam pemerintahan. Anggaran daerah merupakan rencana keuangan yang menjadi dasar dalam pelaksanaan pelayanan publik. Di Indonesia dokumen anggaran daerah disebut anggaran pendapatan dan belanja daerah (APBD), baik untuk provinsi maupun kabupaten dan kota. Proses penyusunan anggaran pasca UU 22/1999 (dan UU Nomor 32 Tahun 2004) melibatkan dua pihak yaitu eksekutif dan legislatif, masing-masing melalui sebuah tim atau panitia anggaran.

Permasalahan yang muncul dalam teori keagenan cenderung memfokuskan pada perilaku yang disyaratkan kepada agent sesuai dengan keinginan principal. Padahal, dalam praktiknya principal juga bertanggung jawab karena memengaruhi kinerja agent melalui sejumlah kebijakan. Permasalahan ini terlihat pada apa yang terjadi di Desa Pabelan. Keterlambatan penerbitan 
Perbup yang menjadi dasar penyusunan APBDes menyebabkan pihak desa terlambat menyusun APBDes. Hubungan ini menjalin rantai sebabakibat. Sehingga dapat kita ketahui bahwa pemerintah daerah juga bertanggung jawab atas pertanggungjawaban dana desa, dalam hal ini yang berkaitan dengan publikasi kepada masyarakat.

3) Ketidaksinkronan informasi

Berdasarkan hasil wawancara yang telah dilakukan mengenai pertanggungjawaban dana desa di Desa Pabelan terdapat perbedaan informasi yang dipaparkan oleh narasumber 1 dan narasumber 2. Pewawancara menanyakan pertanyaan yang sama kepada kedua narasumber akan tetapi jawaban dari keduanya berbeda. Contohnya mengenai syarat pencairan dana desa, narasumber 1 menyatakan bahwa desa harus menyerahkan SPJ dan LPJ pengalokasian dana yang diterima di tahap satu sebagai syarat pencairan dana desa tahap selanjutnya. Akan tetapi narasumber 2 menyatakan bahwa terkadang pelaporan tersebut hanya berupa pelaporan progres alokasi dana yaitu minimal sebanyak $75 \%$. Idealnya memang yang dilaporkan adalah SPJ dan LPJ namun dalam pelaksanaan di Desa Pabelan tidaklah demikian.

Selain itu, narasumber 1 menyatakan bahwa pemublikasian APBDes di Desa Pabelan sudah merata di seluruh dusun akan tetapi narasumber 2 menyatakan bahwa hal tersebut baru terjadi pada tahun 2018 dimana pada tahun 2017 pemasangan MMT sebagai bentuk publikasi hanya terdapat di beberapa dusun sehingga dapat dikatakan bahwa publikasi tersebut belum merata. Lebih lanjut mengenai publikasi kepada masyarakat, pada tahun 2015 dan 2016 Desa Pabelan belum melaksanakan hal tersebut dimana narasumber 1 menyatakan bahwa penyebabnya adalah kurangnya pemahaman dari perangkat desa sedangkan narasumber 2 menyatakan bahwa hal tersebut terjadi karena belum adanya instruksi dari atasan untuk membuat MMT. Untuk kedepannya antar perangkat desa harus menjalin komunikasi yang baik agar tidak terjadi perbedaan penerimaan informasi. Selain itu diharapkan perangkat desa lebih terbuka ketika diwawancarai.

\section{KESIMPULAN}

\section{Kesimpulan}

Pertanggungjawaban dana desa di Desa Pabelan Kabupaten Semarang dilakukan dengan melaporkan penggunaan dana desa setiap tahap pencairan lalu melaporkan Laporan Pertanggungjawaban Realisasi Pelaksanaan APBDes pada akhir tahun serta mempublikasikan APBDes serta realisasinya kepada masyarakat melalui pemasangan MMT. Hal ini menunjukkan bahwa pelaksanaan pertanggungjawaban dana desa disana belum sesuai dengan Permendagri No 113 tahun 2014. Dimana ada beberapa hal yang belum dilaksanakan oleh perangkat desa. Sehingga dapat ditarik kesimpulan bahwa pelaksanaan pertanggungjawaban dana desa di Kabupaten Semarang belum berjalan dengan baik.

Pelaksanaan pertanggungjawaban dana desa di Desa Pabelan Kabupaten Semarang belum terlaksana dengan baik karena terdapat berbagai permasalahan yang dihadapi tepatnya di Desa Pabelan. Permasalahan tersebut meliputi laporan yang disampaikan kepada Bupati belum lengkap yaitu tidak adanya Laporan Kekayaan Milik Desa dan Laporan Program Pemerintah dan Pemerintah Daerah yang Masuk ke Desa, laporan pertanggungjawaban realisasi pelaksanaan APBDes terlambat diinformasikan kepada masyarakat yaitu pada awal penerimaan dana desa (2015-2016) serta pada tahun 2019 pun terlambat, dan ketidaksinkronan informasi yang disampaikan oleh para informan yang diwawancarai.

\section{Rekomendasi}

Berdasarkan dari permasalahan-
permasalahan yang ada dalam praktik pertanggungjawaban dana desa di Desa Pabelan di atas saran dari peneliti yaitu diharapkan adanya pelatihan secara intensif agar kualitas perangkat desa menjadi lebih baik sehingga dapat menyusun laporan keuangan secara lengkap. Kemudian diharapkan perangkat desa lebih berinisiatif serta tanggap dalam pelaksanaan pertanggungjawaban dana desa. Kedepannya diharapkan agar antar perangkat desa lebih terbuka sehingga tidak terjadi asimetric information. Selain itu juga diharapakan perangkat desa lebih transparan dalam penyampaian informasi. 


\section{UCAPAN TERIMA KASIH}

Dengan terselesaikannya penelitian ini, kami mengucapkan terima kasih kepada pihak Pemerintah Desa Pabelan yang telah memberikan informasi mengenai penelitian kami. Terima kasih juga kepada dosen pembimbing yang senantiasa membimbing kami dalam menulis penelitian ini, sehingga penelitian ini dapat berjalan dengan lancar dan juga menghasilkan ilmu yang bermanfaat bagi para pembaca. Untuk yang terakhir terima kasih kepada teman-teman atas dukungan dan motivasinya sehingga kami daat menyelesaikan penelitian ini.

\section{REFERENSI}

Farida, V., Jati, A. W., \& Harventy, R. (2018). Analisis Akuntabilitas Pengelolaan Alokasi Dana Desa (Add) di Kecamatan Candipuro Kabupaten Lumajang. Jurnal Akademi Akuntansi, 1(11), 64-73.

Herdiansyah, H. (2013). Wawancara, Observasi, dan Focus Group Sebagai Instrumen Penggalian Data Kualitatif. Jakarta: Rajawali Press.

Jensen, M. C., \& Meckling, W. H. (1976). Theory of the Firm: Managerial, Agency Cost and Ownership Structure. Journal of Financial Economics, 3, 305-360. https://doi.org/http://dx.doi.org/10.1016/03 04-405X(76)90026-X

Kurnia, R., Sebrina, N., \& Halmawati. (2019). Akuntabilitas Pengelolaan Dana Desa (Studi Kasus pada Desa-Desa di Wilayah Kecamatan Lubuk Nan Duo Kabupaten Pasaman Barat). Jurnal Eksplorasi Akunransi, 1(1), 159-180.

Madjid, T. (2017). Kebijakan Penetapan Prioritas Penggunaan Dana Desa Tahun 2017. Retrieved October 15, 2017, from http://www.djpk.depkeu.go.id/wpcontent/uploads/2016/11/paparan-
kemendesPDTT.pdf

Orangbio, vega virjinia, Tinangon, J., \& Gerungai, N. (2017). Analisis Perencanaan dan Pertanggungjawaban Apbdes menurut Peraturan Menteri Dalam Negeri Nomor 113 Tahun 2014 dalam Upaya Meningkatkan Pembangunan Desa. 12(2), 53-60.

Siti Ainul Wida, D. S., \& Taufik Kurrohman. (2017). Akuntabilitas Pengelolaan Alokasi Dana Desa ( ADD ) di Desa - Desa Kecamatan Rogojampi Kabupaten Banyuwangi ( The Accountability in the Management of the Village Fund Allocation in Villages at Rogojampi District, Banyuwangi Regency ). E-Journal Ekonomi Bisnis Dan Akuntansi, IV(2), 148-152.

Sugiyono. (2007). Statistika untuk Penelitian. CV. Alfabeta.

Sulumin, H. H. (2015). Pertanggungjawaban Penggunaan Alokasi Dana Desa Pada Pemerintahan Desa di Kabupaten Donggala. E-Jurnal Katalogis, 3(1), 43-53. Retrieved from

http://jurnal.untad.ac.id/jurnal/index.php/K atalogis/article/view/4246/3161

Tikollah, M. R., \& Ngampo, M. Y. A. (2018). Analisis pengelolaan alokasi dana desa (add) di kecamatan mare kabupaten bone. 1(1), 8796.

Utomo, K. S., Sudarmo, \& Suharto, D. G. (2018). Analisis Good Governance Dalam Pengelolaan Keuangan Desa Analysis of Good Governance in Village Financial Management. 13(April), 50-66.

Winari, E. D. (2018). Pertanggungjawaban Pidana Dalam Pengelolaan Dana Desa Berdasarkan PP Nomor 8 Tahun 2016 (Studi Kasus Di Desa Srikaton Kecamatan Jaken Kabupaten Pati. 1(1), 271-282.

Zelmiyanti, R. (2016). Pendekatan Teori Keagenan Pada Kinerja Keuangan Daerah Dan Belanja Modal (Studi Pada Provinsi Di Indonesia). Jrak, 7(1), 11-21. 